Research Note

Journal of Extension Education

Vol. 29 No. 1, 2017

DOI:https: / / doi.org/10.26725/JEE.2017.1.29.5818-5822

\title{
Constraints Perceived by Students in School Vegetable Gardening
}

\section{S. Dilip ${ }^{1}$ and Allan Thomas ${ }^{2}$}

\begin{abstract}
The study was conducted in Thiruvananthapuram district of Kerala to identify the constraints experienced by students in the course of engaging in school vegetable gardening programme. Ten schools were selected for data enumeration. A total of 130 respondents with 100 students comprising ten students each and 30 teachers comprising three each, from each school were selected for meeting the objectives of the study. The reaction to each constraint was obtained on a four-point continuum namely most important, important, less important and least important with the score 4, 3, 2 and 1 respectively. Mean rank cumulative index for each constraint was worked out and the constraints were ranked and catalogued. The major constraints as perceived by students in school vegetable garden projects were, high input cost followed by lack of student's participation, lack of teacher's involvement, non-availability of implements, high labour cost, poor storage facilities and lack of knowledge about gardening.
\end{abstract}

Keywords : School; constraints; vegetable garden;

The vegetable garden considered as livelihood laboratory, engages students by providing an energetic environment for them to observe, discover, experiment, nurture, and learn. Lessons are internalized from real-life experiences rather than textbook examples, thus, allowing students to become active

Participants in the learning process. Vegetables that form an important dietary requirement for the healthy development of a child necessitate specific programmes to sensitize them on the art and science of vegetable growing.
In case of Kerala, more than 70 per cent of the vegetable requirement is met from the neighboring states like Tamil Nadu, Karnataka and Andhra Pradesh. Kerala also has the limitation of land for agriculture owing to the high rate of fragmentation of land due to population pressure, increasing nucleotide family structure, and other demo-ecographic positioning (Thomas, 2004). One way to address the issue of vegetable shortage is to scale up its production in schools using the under or unused lands and the young energy. To address this, many projects have been initiated by the Kerala

1. PG Scholar and 2. Assistant Professor, Department of Agricultural Extension, College of Agriculture, Kerala Agricultural University, Vellayani- 695522 
Government. The Vegetable and Fruits Promotion Council Kerala (VFPCK) has initiated a programme to develop vegetable gardens in 1,000 schools as part of itsagri@schoolprogramme aimed at cultivating interest in agriculture among school children wherein 15 cents of land was used for vegetable gardens in schools with an objective to produce 600 tonnes of vegetables harnessing the vibrant energy of students in schools. ("Vegetable garden plants in school”, 2006).

\section{METHODOLOGY}

Ten best performing schools in vegetable gardening were purposively selected in consultation with the officials of Directorate of Public Instruction (DPI) of Thiruvananthapuram district. Ten active volunteers who were participating in the school vegetable gardening activities were selected at random from 10 schools after consulting with the respective school teachers. Thus a total of 100 student respondents were selected for the study. Based on discussion with

It is evident from Table 1 that the major constraints as perceived by students in school vegetable garden were, high input cost followed by lack of student's participation, lack of teacher's involvement, non-availability of implements, high labour cost, poor storage facilities and lack of knowledge about gardening etc. Other constraints perceived by students in school vegetable garden included scarce water resource, school students and teachers involved in school vegetable gardening and also through relevant literature search, 25 constraints were identified and the responses of students were elicited through personal interview. The reaction to each constraint was obtained on a four-point continuum namely most important, important, less important and least important with the score 4, 3, 2 and 1 respectively. Mean rank cumulative index for each constraint was worked out and the constraints were ranked and catalogued.

\section{FINDINGS AND DISCUSSION}

Students face a number of limitations in growing school vegetable garden and gardening activities. Constraints experienced by the students were identified, ranked and presented as a list. The constraint with the highest score was designaed as the major constraint. The results of constraints faced by students in managing their vegetable garden are presented in Table 1.

inadequate capital, lack of student's interest and lack of plant protection implements in the order of decreasing importance. These observations reflect the findings of Monroe \& Kaplan (1988) and Klein \& Merritt (1994).

The major strategies suggested by the students and teachers screened after discussing with subject matter specialists are presented in Table 2. 
Table 1.

Constraints Perceived by the Students in Managing and Maintaining the School Vegetable Garden

\begin{tabular}{|c|c|c|c|}
\hline \multirow{2}{*}{$\begin{array}{l}\text { S1. } \\
\text { No. }\end{array}$} & \multirow{2}{*}{ Items } & \multicolumn{2}{|c|}{ Students } \\
\hline & & Score & Rank order \\
\hline 1 & High input cost & 360 & 1 \\
\hline 2 & Non availability of labour & 232 & 17 \\
\hline 3 & High labour cost & 282 & 5 \\
\hline 4 & Inadequate capital & 263 & 9 \\
\hline 5 & Lack of student's interest & 263 & 10 \\
\hline 6 & Uneconomic holding & 243 & 15 \\
\hline 7 & Lack of technology & 246 & 14 \\
\hline 8 & Lack of knowledge about gardening & 272 & 7 \\
\hline 9 & Scarce water resource & 266 & 8 \\
\hline 10 & Non availability of credit & 261 & 12 \\
\hline 11 & Poor storage facility & 279 & 6 \\
\hline 12 & Lack of teacher's involvement & 304 & 3 \\
\hline 13 & Lack of student's participation & 314 & 2 \\
\hline 14 & Non availability of implements & 288 & 4 \\
\hline 15 & Lack of protection implements & 263 & 11 \\
\hline 16 & Lack of extension service & 241 & 16 \\
\hline 17 & Lack of time & 247 & 13 \\
\hline 18 & Lack of motivation & 217 & 20 \\
\hline 19 & Poor economic status & 231 & 18 \\
\hline 20 & Surplus but insufficient for marketing & 201 & 21 \\
\hline 21 & Wild animals destroy produce & 225 & 19 \\
\hline 22 & Less profit & 196 & 22 \\
\hline 23 & Lack of proper training & 195 & 23 \\
\hline 24 & Difficult to work & 181 & 24 \\
\hline 25 & Pilferage of vegetables from school & 154 & 25 \\
\hline
\end{tabular}


Table 2.

Suggestions for Refinement for Sustenance of School Vegetable Gardening Programme

\begin{tabular}{|c|l|c|c|}
\hline S1. No. & \multicolumn{1}{|c|}{ Suggestions } & \multicolumn{1}{|c|}{ F } & \multicolumn{1}{|c|}{$\%$} \\
\hline 1 & Good quality inputs at required time and amount & 126 & 96.92 \\
\hline 2 & $\begin{array}{l}\text { Alternative arrangements for garden maintenances } \\
\text { during summer vacations }\end{array}$ & 117 & 90.00 \\
\hline 3 & $\begin{array}{l}\text { Providing adequate number of training for knowledge } \\
\text { enhancement of teachers and students on agricultural } \\
\text { technology and its utilizations by competent subject } \\
\text { matter experts }\end{array}$ & 104 & 80.00 \\
\hline 4 & $\begin{array}{l}\text { Follow up of government schemes/projects with increased } \\
\text { outlay in school vegetable gardens }\end{array}$ & 95 & 73.07 \\
\hline 5 & $\begin{array}{l}\text { Making available of student friendly safe implements to } \\
\text { be used for production and protection activities. }\end{array}$ & 86 & 66.67 \\
\hline School vegetable garden as a compulsory subject in \\
school curriculum
\end{tabular}

The results from Table 2 indicate that majority of the students and teachers (96.92\%) opined that 'good quality inputs at required time and amount' should be made available at school for the un-interrupted and successful conduct of the programme. 'An alternative arrangement for garden maintenance during summer vacations' (90\%) was another felt requirement by both students and teachers.

The school council should consider devising a strategy to engage labour and supervisory team during vacations so that the crops in field are not affected. Also, mechanism to provide incentives for teachers and students who come, attend and manage school vegetable garden could be thought of.

All the above cited measures would improve the overall scenario of school vegetable gardening. This will not only help the overall development of the individuals be it teachers or students, but also will help to bring more area under safe vegetable production helping the socio-economic position of Kerala. There is a growing movement globally for the "greening" of schoolyards through gardens at school sites, and much enthusiasm for the potential of gardenbased learning in promoting healthy youth development(Hedley et al.) Kerala, one of the best performing states in India in terms of literacy should be an example in this case so that others emulate this 
practice developing both the students and society positively.

\section{REFERENCES}

Hedley, A., Ogden, C., Johnson, C., Carroll, M., Curtin, L., \& Flegal, (2004). Overweight and Obesity among U.S. Children, Adolescents and adults. Journal of American Medical Association.291(23), 2847-2850.

Klein, E. S. \& Merritt, E. (1994). Environmental Education as a Model for Constructivist Teaching. Journal of
Environmental Education 25(3), 14-21.

Monroe, M. C. \& Kaplan, S. (1988). When Words Speak Louder Than Actions: Environmental Problem Solving in the Classroom. Journal of Environmental Education. 19(3), 38-41.

Thomas, A. (2004). Technology Assessment in the Home Garden Systems. Unpublished Ph. D. thesis, Kerala Agricultural University, Thrissur, 230p.

Vegetable garden plants in school (2006, June 24), The Hindu. 